\title{
Physiological quality of soybean seeds produced under artificial rain in the pre-harvesting period ${ }^{1}$
}

\author{
Elisa de Melo Castro ${ }^{2}$, João Almir Oliveira², Amador Eduardo de Lima², \\ Heloísa Oliveira dos Santos² ${ }^{2}$ José Igor Lopes Barbosa²
}

\begin{abstract}
The objective of this experiment was to evaluate responses of soybean cultivars seeds (with different levels of lignin) considering harvest postponement under the incidence of water and the effect of storage. The experiment was conducted in Iraí de Minas, Brazil using a randomized block design with three replications under a 5 x 3 x 3 factorial arrangement, with five soybean cultivars (NK 7059 RR, SYN 1163 RR, SYN 9070 RR, AS 7307 RR and SYN 1283 RR), three harvesting periods ( $R 8, R 8+$ one rain simulation in the pre-harvesting period and $R 8$ + two simulations in the pre-harvesting period) under three storage times ( 0,90 and 180 days). Seeds were evaluated for their chemical composition (lignin contents), the percentage of moisture damage using the tetrazolium test and physiological quality (germination, accelerated aging, conductivity test, seedling emergence and emergence index). Cultivar AS 7307 RR had the highest lignin content in the integument, the lowest percentage of damage by moisture and the highest physiological quality. Cultivars NK 7059 RR and SYN 1163 RR had the lowest lignin contents in the integument and the highest moisture damage. Electrical conductivity increased after storing all cultivars.
\end{abstract}

Index terms: Glycine max, lignin, storage.

\section{Qualidade fisiológica de sementes de soja submetidas à chuva artificial na pré-colheita}

\begin{abstract}
RESUMO - Objetivou-se com este trabalho avaliar o desempenho de sementes de cultivares de soja com diferentes teores de lignina considerando o retardamento da colheita sob incidência artificial de chuva, e ao longo do armazenamento. $\mathrm{O}$ ensaio foi conduzido em Iraí de Minas, MG, em blocos casualizados com três repetições e esquema fatorial 5 x 3 x 3, sendo cinco cultivares de soja (NK 7059 RR, SYN 1163 RR, SYN 9070 RR, AS 7307 RR e SYN 1283 RR), três épocas de colheita (R8, R8 + uma simulação de chuva na pré-colheita e R8 + duas simulações de chuva na pré-colheita), e três épocas de armazenamento (0, 90 e 180 dias). As sementes foram avaliadas quanto à composição química (teor de lignina), porcentagem de danos por umidade usando o teste de tetrazólio, e a qualidade fisiológica (germinação, teste de envelhecimento, condutividade elétrica, emergência, índice de emergência). A cultivar AS 7307 RR apresentou maior teor de lignina no tegumento, menor porcentagem de danos por umidade e melhor qualidade fisiológica. As cultivares NK 7059 RR e SYN 1163 RR apresentam menores teores de lignina no tegumento e maiores danos por umidade. Os valores de condutividade elétrica aumentam com o armazenamento para todas as cultivares.
\end{abstract}

Termos para indexação: Glycine max, lignina, armazenamento.

\section{Introduction}

Soybeans (Glycine $\max$ L. Merrill) are one of the most cultivated plants in the world, having great importance in the Brazilian economy. The development of soybean crops is associated with new technologies, especially those related to the production of high quality seeds, free of pathogens and with potential to develop high vigor seedlings (Pelúzio et al., 2008).
Genetic characteristics and environmental effects during the development, harvesting, processing and storage stages are key factors in the seed viability period, which is extremely variable. In seeds submitted to unfavorable conditions in any of these stages there may be physiological damage that can hinder the seeds quality and the intensity of such damage is variable with genetic factors and intrinsic to each cultivar (Gris et al., 2010).

\footnotetext{
${ }^{1}$ Submitted on 9/11/2015. Accepted for publication on 12/4/2015.

${ }^{2}$ Departamento de Agricultura, UFLA, Caixa Postal 3037, 37200-000 - Lavras, MG, Brasil.

*Corresponding author < elisaagro@yahoo.com.br>
} 
Soybean seeds reach their physiological ripening at the R7 stage, when they have maximum physiological quality and should be harvested. Due to this high water content in seeds at this stage, the recommended harvest point is stage R8, when $95 \%$ of the pods have the typical coloration of ripe pods. However, due to several factors, it is not always possible to harvest the seeds at the right time and delayed harvest often occurs (Diniz et al., 2013). Delayed harvest can lead to losses in physiological and sanitary quality of seeds (Henning et al., 2011).

In the period between physiological ripening and harvest, there may be damage by "moisture" in the seeds, which results from their exposure in alternating cycles of wet and dry environmental conditions in the post-ripening phase. Such damage can be even more aggressive in tropical regions, predominantly due to hot and humid weather, which can further accelerate the seeds deterioration process. Forti et al. (2013) have found that the seeds physiological potential is reduced by moisture damage and this may be one of the most detrimental factors to the quality of soybean seeds.

In some research it has been observed that the lignin content of the integument can influence the seeds physiological quality (Panobianco et al., 1999). The possibility of seeds with a certain degree of impermeability that have greater tolerance to deterioration from moisture has motivated researchers. Thus, the aim of this study was to evaluate soybean cultivars seeds performance with different levels of lignin in terms of harvest postponement with artificial incidence of rain during storage.

\section{Material and Methods}

The experiment was conducted in a seed production field deployed in October 2013 in an area irrigated by center-pivot in the Brazilian city of Iraí de Minas, in the state of Minas Gerais. The city is located in the (area in the west of the state of Minas Gerais, Brazil) "Triângulo Mineiro" region under geographical coordinates $18^{\circ} 59^{\prime} 23^{\prime}$ ' LS and 47 28' $33^{\prime}$ 'LW' and altitude of 1029 meters.

The experiment was conducted in a randomized block design with three replications and a $5 \times 3$ factorial arrangement where five cultivars were evaluated: NK 7059 RR, SYN 1163 RR, SYN 9070 RR, AS 7307 RR, SYN 1283 RR and three harvest times: at the R8 stage, in $\mathrm{R} 8$ more rainfall simulation in the pre-harvest, and in R8 two more rain simulations in pre-harvest. Rain simulations were performed by means of a center-pivot irrigation, using an intensity of approximately 30 $\mathrm{mm}$ of water until the pods were soaked and reached $18 \%$ of water content. The plots consisted of six rows of 12 meters with spacing of $0.5 \mathrm{~m}$ between rows and 20 seeds $/ \mathrm{m}$. And the two rows of the central region were used as floor area of the plot. In
March 2014 there was a manual harvesting of plants and drying in the sun until the seeds reached $13 \%$ of water content. Seeds were processed with a plant threshing with beater cylinder. Then they were packed in paper bags and sent to the Brazilian city of Lavras, MG, where they were stored in the Seeds Processing Unit at Federal University of Lavras. Testing were performed on seeds retained in a circular screen 13 sieve.

To characterize the moisture damage caused by the incidence of artificial rain in the pre-harvest, tetrazolium test was performed, which was conducted with four subsamples of 25 seeds per plot, totaling 300 seeds per treatment. Seeds were preconditioned between paper towel moistened with distilled water for 16 hours at $25^{\circ} \mathrm{C}$ and then they were immersed in a 2,3,5-triphenyl-2H-tetrazolium chloride solution) at $0.075 \%$ under temperature of $40^{\circ} \mathrm{C}$ for three hours in the dark. The evaluation was conducted according to the methodology proposed by França-Neto et al. (1998) considering the percentage of seeds with moisture damage. To determine the lignin content in the integument, six replications of 50 seeds were used for each cultivar, following the methodology proposed by Capeleti et al. (2005).

Laboratory testing to evaluate the physiological quality of the seeds were performed with two subsamples of 50 seeds per plot totaling 300 seeds per treatment, performed at zero, 90 and 180 days of storage by the following tests: Germination: according to Brasil (2009); Accelerated aging: gerbox-type transparent acrylic boxes $(11.0 \times 11.0 \times 3.5 \mathrm{~cm})$ were used, adapted with a hanging aluminum screen, containing $40 \mathrm{~mL}$ of distilled water and a single layer of seeds on the hanging screen. Subsequently, these boxes were kept in a B.O.D. (Biochemical Oxygen Demand) at $42^{\circ} \mathrm{C}$ for 72 hours (Dutra and Vieira, 2004). After this period, the seeds were submitted to the germination test. Electrical conductivity: performed with the aid of a digital conductivity meter (Digimed CD-21). Results were expressed in $\mu \mathrm{S} \mathrm{cm}^{-1} \cdot \mathrm{g}^{-1}$ according to the method described by Vieira and Krzyzanowski (1999). Seedling emergence: seeds were sown in plastic trays containing soil and sand as a substrate, in the 2:1 ratio, moistened to $60 \%$ of the moisture holding capacity. The trays were kept in a plant growth chamber at a temperature of $25^{\circ} \mathrm{C}$ and a photoperiod of 12 hours, with daily assessments of normal seedlings emergence and a final score at 14 days after sowing. The final percentage of emergence and emergence speed index (ESI) were considered (Maguire,1962).

For statistical analysis of germination, accelerated aging, electrical conductivity, seedling emergence and emergence speed index tests, the treatments were arranged in a $5 \times 3 \times 3$ factorial design involving five cultivars, three harvest times and three storage times. A complete randomized block design (RBD) with three replications was used. Data were submitted 
to analysis of variance using the statistical program Sisvar (Ferreira, 2011). Means were compared by the Scott-Knott test at $5 \%$ probability.

For the tetrazolium test, statistical analysis was performed separately by considering only the non-stored seeds, and moisture damage values were previously transformed into $(x+1)^{0.5}$ using the statistical program Sisvar in RBD, 5 x 3 factorial arrangement, being five cultivars and three harvest times.

Lignin content was determined for the five cultivars studied and six replicates were analyzed. Statistical analysis was performed separately in a completely randomized design (CRD) using the statistical program Sisvar at 5\% probability.

\section{Results and Discussion}

\section{Lignin content}

There were differences for the five cultivars studied. Cultivar AS 7307 RR showed higher content (0.4433 g\%); cultivars SYN 1283 RR (0.3017 g\%), SYN 9070 RR (0.2967 $\mathrm{g} \%$ ) showed intermediate contents and did not differ from each other. Cultivars SYN 1163 RR (0.2233 g\%) and NK 7059 RR (0.1933 g\%) showed the lowest contents of lignin.

The cultivar with the highest content of lignin, AS 7307 RR (0.4033 g\%), throughout the study showed, in general, better physiological quality (Tables 1, 2, 3, 4, 5). The high physiological quality can be associated with the lignin content.

Menezes et al. (2009) have observed that the highest lignin content is associated with a higher percentage of normal seedlings in the accelerated aging test. However, there was a negative correlation to the germination rate. Santos et al. (2007) have found that soybean seeds with brown integument have a higher lignin content, ranging between 4 and $6 \%$ of lignin compared to the total weight of the integument, and higher vigor due to the slower rate of soaking.

Carvalho et al. (2014) have noticed that soybean cultivar seeds with high lignin content in the integument do not necessarily have better physiological quality. Cultivar Baliza $\mathrm{RR}$, with lignin content of $0.4171 \mathrm{~g} \%$, an intermediate content between the cultivars studied, showed higher physiological quality before and after storage. Thus, seed quality can also be related to other factors inherent in the genotype.

\section{Tetrazolium}

The sources of variation cultivar and harvest season, as well as the interaction between these two factors, significantly differed in the evaluation of the tetrazolium test (damage caused by moisture 1-8).

Comparing cultivars at harvest season R8, it was observed that cultivar AS 7307 RR showed lower percentage of moisture damage (10.67\%), followed by cultivars SYN 9070 RR (22.00\%) and SYN 1283 RR (24.33\%). Cultivars SYN 1163 RR and NK 7059 RR showed higher percentage of damage (45.33\% and 50.33\%, respectively). AS 7307 RR and SYN 9070 RR were present in the group least affected by the effect of moisture in harvest times $\mathrm{R} 8+1$ and $\mathrm{R} 8+2$ (Table 1 ).

Table 1. Percentage of seeds with moisture damage for different soybean cultivars with a delayed harvest.

\begin{tabular}{lccc}
\hline \multirow{2}{*}{\multicolumn{1}{c}{ Cultivar }} & \multicolumn{3}{c}{ Harvest season } \\
\cline { 2 - 4 } & $\mathrm{R} 8$ & $\mathrm{R} 8+1$ & $\mathrm{R} 8+2$ \\
\hline NK 7059 RR & $50.33 \mathrm{Ac}$ & $51.20 \mathrm{Ab}$ & $63.14 \mathrm{Ab}$ \\
SYN 1163 RR & $45.33 \mathrm{Ac}$ & $52.00 \mathrm{Ab}$ & $50.67 \mathrm{Ab}$ \\
SYN 9070 RR & $22.00 \mathrm{Ab}$ & $35.00 \mathrm{Ba}$ & $21.67 \mathrm{Aa}$ \\
AS 7307 RR & $10.67 \mathrm{Aa}$ & $39.33 \mathrm{Ba}$ & $28.33 \mathrm{Ba}$ \\
SYN 1283 RR & $24.33 \mathrm{Ab}$ & $26.67 \mathrm{Aa}$ & $41.67 \mathrm{Bb}$ \\
\hline
\end{tabular}

Means followed by the same letter, lowercase in the column and uppercase in the row, do not differ at 5\% probability by the Scott-Knott test. R8: harvest stage; $\mathrm{R} 8+1$ : harvest stage $\mathrm{R} 8$ plus one rain simulation in the pre-harvest and $\mathrm{R} 8+2$ : harvest stage $\mathrm{R} 8$ plus two rain simulations in the pre-harvest. The original means were presented, but data were compared according to the data transformed (Transformation in $\left.(\mathrm{x}+1)^{0.5}\right)$.

For cultivars AS 7307 RR and SYN 1283 RR, it was observed that the stress caused by the delayed harvest, coupled with humidity, caused an increase in the percentage of moisture damage. The simulation of one and two rains in the pre-harvest did not cause an increase in the percentage of moisture damage for NK 7059 RR and SYN 1163 RR. However, there was a higher frequency of damage in three harvest times for these cultivars. Genotype AS 7307 RR had a higher lignin content and a lower percentage of moisture damage in the three harvest times (Table 1).

Forti et al. (2013), studying moisture damage in soybean seeds, related tetrazolium test results with image analysis by $\mathrm{X}$-ray and confirmed that moisture damage interferes with the seeds physiological potential, depending on their extent and location. Giurizatto et al. (2003) have observed that the vigor estimated by the tetrazolium test was influenced by the harvest season and the genotypes. Higher percentages of vigor were obtained when the harvest was held at the R 8 stage and delayed harvest caused a reduction in vigor. In this study, it is noted that the increase in the percentage of moisture damage with a delayed harvest occurred only to cultivars AS 7307 RR and SYN 1283 RR, enhancing the effect of genotype for each harvest season.

\section{Physiological analyses}

For the results of the physiological tests, the sources of variation cultivar and harvest season significantly influenced 
all response variables. Regarding storage, there was no statistical difference for electrical conductivity, accelerated aging, emergence speed index and percentage of emergence at 14 days in the emergence test. For interactions, there was a significant effect cultivar*harvest season in all tests, cultivar*storage for electrical conductivity, emergence speed index and germination percentage at 14 days in the emergence test. For the interaction harvest season*storage time, only in the electrical conductivity test there was a significant effect. There was no significant effect for triple interaction (cultivar*harvest season*storage time).

\section{Germination}

Regarding the interaction cultivar*harvest season, it is noted that in the R8 harvest season the five cultivars studied were statistically different. For harvest season R8 + 1, cultivar AS 7303 RR showed germination percentage statistically equal to cultivar SYN 1283 RR, which were higher than the others. Cultivar SYN 1163 RR showed lower performance. For harvest season R8 + 2, all cultivars showed high germination percentages, and cultivars AS 7307 RR, SYN 9070 RR, SYN 1163 RR and NK 7059 RR did not differ from each other and showed higher germination percentage than cultivar SYN 1283 RR (Table 2).

Table 2. Seed germination, electrical conductivity, accelerated aging in different soybean cultivars with a delayed harvest.

\begin{tabular}{|c|c|c|c|c|c|c|c|c|c|}
\hline \multirow{2}{*}{ Cultivars } & \multicolumn{3}{|c|}{ Germination (\%) } & \multicolumn{3}{|c|}{ Electrical conductivity $\left(\mathrm{uS} \mathrm{cm} \mathrm{cm}^{-1} \cdot \mathrm{g}^{-1}\right)$} & \multicolumn{3}{|c|}{ Accelerated aging $(\%)$} \\
\hline & $\mathrm{R} 8$ & $\mathrm{R} 8+1$ & $\mathrm{R} 8+2$ & $\mathrm{R} 8$ & $\mathrm{R} 8+1$ & $\mathrm{R} 8+2$ & $\mathrm{R} 8$ & $\mathrm{R} 8+1$ & $\mathrm{R} 8+2$ \\
\hline NK 7059 RR & $83 \mathrm{Bc}$ & $81 \mathrm{Bb}$ & $90 \mathrm{Aa}$ & $62.94 \mathrm{Ab}$ & $72.24 \mathrm{Ba}$ & $68.58 \mathrm{Ba}$ & $48 \mathrm{Bb}$ & $51 \mathrm{Bc}$ & $69 \mathrm{Ab}$ \\
\hline SYN 1163 RR & $66 \mathrm{Be}$ & $64 \mathrm{Bd}$ & $91 \mathrm{Aa}$ & $82.47 \mathrm{Bc}$ & $88.45 \mathrm{Bc}$ & $74.11 \mathrm{Ab}$ & $32 \mathrm{Bc}$ & $35 \mathrm{Bd}$ & $73 \mathrm{Ab}$ \\
\hline SYN 9070 RR & $78 \mathrm{Bd}$ & $72 \mathrm{Cc}$ & $93 \mathrm{Aa}$ & $76,58 \mathrm{Bc}$ & $81,07 \mathrm{Bb}$ & $66,76 \mathrm{Aa}$ & $53 \mathrm{Bb}$ & $52 \mathrm{Bc}$ & $89 \mathrm{Aa}$ \\
\hline AS 7307 RR & $98 \mathrm{Aa}$ & $92 \mathrm{Ba}$ & $94 \mathrm{Ba}$ & $51.55 \mathrm{Aa}$ & $65.87 \mathrm{Ba}$ & $63.80 \mathrm{Ba}$ & $94 \mathrm{Aa}$ & $84 \mathrm{Aa}$ & $88 \mathrm{Aa}$ \\
\hline SYN 1283 RR & $89 \mathrm{Ab}$ & $88 \mathrm{Aa}$ & $86 \mathrm{Ab}$ & $63.67 \mathrm{Ab}$ & $67.83 \mathrm{Aa}$ & $74.34 \mathrm{Bb}$ & $86 \mathrm{Aa}$ & $72 \mathrm{Bb}$ & $72 \mathrm{Bb}$ \\
\hline
\end{tabular}

Means followed by the same letter, lowercase in the column and uppercase in the row, do not differ at 5\% probability by the Scott-Knott test. R8: harvest stage; $\mathrm{R} 8+1$ : harvest stage R8 plus one rain simulation in the pre-harvest and R8 + 2: harvest stage R8 plus two rain simulations in the pre-harvest.

Considering the breakdown of harvest times in the variation source cultivar, it may be noted that with the exception of cultivars AS 7307 RR and SYN 1283 RR, the others showed higher germination percentage in season $\mathrm{R} 8+$ 2 (Table 2). Cultivar AS 7307 RR, with higher lignin content, had a higher germination percentage at harvest season $\mathrm{R} 8$, and the germination percentages in times $\mathrm{R} 8+1$ and $\mathrm{R} 8+2$ did not differ statistically. Cultivar SYN 1283 RR had germination percentage statistically equal for the three harvest times.

Giurizatto et al. (2003), studying nine genotypes harvested at the R8 stage and at 14 days after this stage, found that delayed harvest reduced germination, and the occurrence of rainfall close in time to the harvest season was possibly one of the factors contributing to seeds deterioration. These findings do not corroborate those of the present study. Probably the artificial incidence of rain coupled with the delayed harvest did not occur in sufficient quantities to cause deterioration in seeds.

Lima et al. (2007) have realized that the germination potential tends to decrease as the seeds remain in the field after physiological ripening, and this fact has not occurred in this study. However, these authors allowed a longer time of exposure to the elements, since the seeds remained in the field until stage R8, R8 +15 days and R8 +30 days. Minuzzi et al. (2010) indicate that obtaining higher quality of seeds occurs when the crop is carried out seven days after stage R7.

\section{Electrical conductivity}

As for the interaction cultivar*harvest season, it is possible to see that cultivar AS 7307 RR was placed in the group of lower electrical conductivity in the three harvest times. Cultivar SYN 1163 RR was placed among cultivars with higher values of electrical conductivity in the three harvest times, behaving physiologically lower than the others (Table 2).

Analyzing the behavior of cultivars in the three harvest times, it can be seen that cultivars AS 7307 RR, NK 7059 RR and SYN 1283 RR had a tendency to increase the electrical conductivity with delayed harvest, showing quality loss (Table 2). For cultivar AS 7307 RR, a positive correlation with the germination test is observed, where there was a decrease of germination vigor with a delayed harvest (Table 2).

Considering the conductivity results of the seeds nonsubmitted to storage, cultivar SYN 1163 RR showed higher electrical conductivity than the others studied. When analyzing the values of electrical conductivity at 90 and 180 days of storage, there was a stratification of cultivars in three lots of vigor, and cultivar AS 7307 RR was superior individually, indicating high physiological potential. Cultivars SYN 1283 RR and NK 7059 RR are shown to be intermediate and cultivars SYN 1163 RR and SYN 9070 RR were considered as having less vigor due to showing higher values of electrical conductivity (Table 3 ). 
Analyzing each cultivar during storage time, a correlation between the increase in the amount of leached ones in the soaking solution, i.e., greater release of exudates that occurs over time, was found. For cultivars SYN 1163 RR and SYN 9070 RR, a gradual and significant increase in the electrical conductivity values for the storage times was seen. As for cultivars NK 7059 RR, AS 7307 RR and SYN 1283 RR, there was an increase of the electrical conductivity value of the first season for the 90 days of storage. However, this behavior was stabilized in this period, with no increased electrical conductivity at 180 days of storage (Table 3 ).

Changes in electrical conductivity among cultivars were noticed by Oliveira et al. (2012) when evaluating soybeans seeds physical, physiological and sanitary quality of two regions in the Brazilian state of Mato Grosso. Panobianco et al. (1999) have noticed the existence of close links between lignin content of soybean cultivars and the results of the electrical conductivity test, which was also observed in this study, since cultivar AS 7307 RR showed higher lignin content and lower electrical conductivity values in the three harvest times.

Generally it is observed that for non-stored seeds harvest season did not influence electrical conductivity values. Lower electrical conductivity with 90 days of storage for seeds of all crops when harvested in R8 was observed. At 180 days, the highest electrical conductivity values were found in the seeds of all cultivars when harvested in the $\mathrm{R} 8$ stage with one rain simulation. Whereas in each harvest season it is possible to identify the increase of electrical conductivity with increasing storage period, indicating increased permeability and loss of membrane integrity with storage time evolution (Table 4).

Table 3. Electrical conductivity of the seeds, emergence and emergence speed index in different soybean cultivars during storage $(0,90,180$ days $)$.

\begin{tabular}{|c|c|c|c|c|c|c|c|c|c|}
\hline \multirow{2}{*}{ Cultivar } & \multicolumn{3}{|c|}{ Conductivity $\left(\mathrm{uS} \mathrm{cm} \mathrm{cm}^{-1} \cdot \mathrm{g}^{-1}\right)$} & \multicolumn{3}{|c|}{ Emergence (\%) } & \multicolumn{3}{|c|}{ ESI } \\
\hline & 0 & 90 & 180 & 0 & 90 & 180 & 0 & 90 & 180 \\
\hline NK 7059 RR & $53.35 \mathrm{Aa}$ & $71.44 \mathrm{Bb}$ & $78.36 \mathrm{Bb}$ & $87 \mathrm{Ab}$ & $77 \mathrm{Bc}$ & $91 \mathrm{Aa}$ & $13.51 \mathrm{Ab}$ & $8.79 \mathrm{Cb}$ & $10.98 \mathrm{Bb}$ \\
\hline SYN 1163 RR & $63.27 \mathrm{Ab}$ & $84.02 \mathrm{Bc}$ & $97.74 \mathrm{Cc}$ & $78 \mathrm{Ac}$ & $66 \mathrm{Bd}$ & $79 \mathrm{Ac}$ & $11.81 \mathrm{Ac}$ & $7.60 \mathrm{Cb}$ & $9.50 \mathrm{Bc}$ \\
\hline SYN 9070 RR & $53.60 \mathrm{Aa}$ & $78.87 \mathrm{Bc}$ & $91.94 \mathrm{Cc}$ & $87 \mathrm{Ab}$ & $81 \mathrm{Ab}$ & $85 \mathrm{Ab}$ & $13.78 \mathrm{Ab}$ & $10.15 \mathrm{Ba}$ & $10.42 \mathrm{Bc}$ \\
\hline AS 7307 RR & $48.07 \mathrm{Aa}$ & $63.31 \mathrm{Ba}$ & $69.86 \mathrm{Ba}$ & $97 \mathrm{Aa}$ & $88 \mathrm{Ba}$ & $95 \mathrm{Aa}$ & $15.55 \mathrm{Aa}$ & $10.20 \mathrm{Ca}$ & $12.09 \mathrm{Ba}$ \\
\hline SYN 1283 RR & $54.40 \mathrm{Aa}$ & $72.75 \mathrm{Bb}$ & $78.68 \mathrm{Bb}$ & $93 \mathrm{Aa}$ & $75 \mathrm{Bc}$ & $94 \mathrm{Aa}$ & $13.68 \mathrm{Ab}$ & $8.23 \mathrm{Cb}$ & $11.31 \mathrm{Bb}$ \\
\hline
\end{tabular}

Means followed by the same letter, lowercase in the column and uppercase in the row, do not differ at $5 \%$ probability by the Scott-Knott test.

Table 4. Electrical conductivity $\left(\mathrm{uS} \mathrm{cm}^{-1} \cdot \mathrm{g}^{-1}\right)$ of soybean seeds submitted to a delayed harvest and stored.

\begin{tabular}{cccc}
\hline \multirow{2}{*}{ Harvest season } & \multicolumn{3}{c}{ Storage (days) } \\
\cline { 2 - 4 } & 0 & 90 & 180 \\
\hline $\mathrm{R} 8$ & $51.49 \mathrm{Aa}$ & $63.38 \mathrm{Ba}$ & $81.45 \mathrm{Ca}$ \\
$\mathrm{R} 8+1$ & $55.32 \mathrm{Aa}$ & $78.82 \mathrm{Bb}$ & $91.43 \mathrm{Cb}$ \\
$\mathrm{R} 8+2$ & $56.75 \mathrm{Aa}$ & $74.18 \mathrm{Bb}$ & $77.53 \mathrm{Ba}$ \\
\hline
\end{tabular}

Means followed by the same letter, lowercase in the column and uppercase in the row, do not differ at 5\% probability by the Scott-Knott test. R8: harvest stage; R8 + 1: harvest stage R8 plus one rain simulation in the pre-harvest and $\mathrm{R} 8+2$ : harvest stage $\mathrm{R} 8$ plus two rain simulations in the pre-harvest.

\section{Accelerated aging}

For soybean seeds vigor, assessed by the accelerated aging test (Table 2), there was a higher germination percentage after aging for cultivars AS 7307 RR and SYN 1283 RR when harvested in R8, AS 7307 RR when harvested in R8 + 1, AS 7307 RR and SYN 9070 RR when harvested in R8 + 2 .

Analyzing the effect of the harvest season for each cultivar, it is possible to see that the result was similar to that observed in the germination test (Table 2). From cultivars with the highest levels of vigor on the sample taken in stage
R8, cultivar AS 7307 RR maintained physiological quality when the harvest was delayed, while SYN 1283 RR showed decline in the germination percentage after accelerated aging with a delayed harvest (Table 2).

Gris et al. (2010) have observed that the largest decreases in vigor for soybean seeds, evaluated by the accelerated aging test, occurred for cultivars Jataí and Silvânia RR when delaying the harvest. When searching for the response from 15 soybean genotypes with delayed harvest, Braccini et al. (2003) have also observed a significant reduction in the germination percentage and seed vigor when they were submitted to harvest 30 days after the R8 stage of development.

\section{Emergence}

Cultivar AS 7307 RR had the highest emergence percentage of seedlings in the three harvest times, being statistically equal to cultivar SYN 1283 RR when harvested in R8 + 1 and SYN 9070 RR when harvested in R8 + 2. SYN $1163 \mathrm{RR}$ was among the cultivars with lower performance in all harvest times (Table 5).

There was an uneven behavior for the cultivars studied when analyzing the effect of delayed harvest. Seeds of cultivars 
NK 7059 RR and AS 7307 RR showed high physiological quality when harvested in $\mathrm{R} 8$ and $\mathrm{R} 8+2$, and seeds of cultivars
SYN 1163 RR and SYN 9070 RR in R8 + 2. Cultivar SYN 1283 RR did not differ statistically for harvest times (Table 5).

Table 5. Seeds emergence and emergence speed index in different soybean cultivars with a delayed harvest.

\begin{tabular}{lcccrrr}
\hline \multirow{2}{*}{ Cultivars } & \multicolumn{3}{c}{ Emergence (\%) } & \multicolumn{2}{c}{ ESI } \\
\cline { 2 - 6 } & $\mathrm{R} 8$ & $\mathrm{R} 8+1$ & $\mathrm{R} 8+2$ & $\mathrm{R} 8+1$ & $\mathrm{R} 8+2$ \\
\hline NK 7059 RR & $85 \mathrm{Ab}$ & $78 \mathrm{Bb}$ & $90 \mathrm{Ab}$ & $10.98 \mathrm{Ab}$ & $10.64 \mathrm{Ab}$ & $11.51 \mathrm{Ab}$ \\
SYN 1163 RR & $71 \mathrm{Bc}$ & $63 \mathrm{Cc}$ & $89 \mathrm{Ab}$ & $9.23 \mathrm{Bc}$ & $7.91 \mathrm{Cc}$ & $11.76 \mathrm{Ab}$ \\
SYN 9070 RR & $82 \mathrm{Bb}$ & $77 \mathrm{Bb}$ & $93 \mathrm{Aa}$ & $11.61 \mathrm{Bb}$ & $9.90 \mathrm{Cb}$ & $12.84 \mathrm{Aa}$ \\
AS 7307 RR & $96 \mathrm{Aa}$ & $89 \mathrm{Ba}$ & $95 \mathrm{Aa}$ & $13.07 \mathrm{Aa}$ & $11.99 \mathrm{Aa}$ & $12.79 \mathrm{Aa}$ \\
SYN 1283 RR & $88 \mathrm{Ab}$ & $88 \mathrm{Aa}$ & $85 \mathrm{Ab}$ & $11.13 \mathrm{Ab}$ & $11.06 \mathrm{Ab}$ & $11.03 \mathrm{Ab}$ \\
\hline
\end{tabular}

Means followed by the same letter, lowercase in the column and uppercase in the row, do not differ at 5\% probability by the Scott-Knott test. R8: harvest stage; $\mathrm{R} 8+1$ : harvest stage R8 plus one rain simulation in the pre-harvest and R8 + 2: harvest stage R8 plus two rain simulations in the pre-harvest.

Diniz et al. (2013), when studying the relationship between the seeds physiological quality of eight soybean cultivars submitted to three harvest times, found that seedling emergence in the field of seeds harvested 30 days after the R8 stage showed lower seedling emergence than those harvested in stages $\mathrm{R} 8$ and $\mathrm{R} 8+15$ days. This behavior was not found in this study. Possibly, delayed harvest combined with artificial incidence of rainfall did not occur in sufficient time and/or quantity to cause this physiological wear on seeds.

There are variations during the storage in the behavior of cultivars (Table 3). Except for cultivar SYN 9070 RR, which did not differ statistically for storage periods, there are larger emergence percentages of normal seedlings for stored and non-stored seeds for 180 days. At 90 days of storage there was a decrease in the emergence percentage.

Schuab et al. (2006) point out that the interpretation of the laboratory and field emergence tests results should not consider only the correlation analysis, as this can lead to incorrect interpretations due to insufficient data.

\section{Emergence speed index}

It is noted that the ESI varied among cultivars, with higher values seen for seedlings of cultivar AS 7307 RR, which presented indices of 13.07, 11.99 and 12.79 when the seeds were collected in $\mathrm{R} 8, \mathrm{R} 8+1$ and $\mathrm{R} 8+2$, respectively. In stage R8 +2 it did not differ statistically from cultivar SYN 9070 RR (Table 5).

SYN 1163 RR was among the cultivars that had the lowest levels of vigor in every harvest season (Table 5). Low vigor seeds take time for the restoration of organelles and damaged tissues before commencing the embryonic axis growth (Villiers, 1973).

Observing the effect of delayed harvest (Table 5), it can be seen that seeds from cultivars SYN 1163 RR and SYN 9070 RR had higher values of emergence speed index when harvested in $\mathrm{R} 8+2$, followed by the seeds that received treatment R8 and later by those which were collected in R8 +1 . These results not corroborate those found by Gris et al. (2010), who observed lower emergence speed in soybean seeds collected in stage $\mathrm{R} 8+20$ in relation to that observed in seeds collected in stages R7 and R8.

For non-stored seeds (Table 3 ), there was a predominance of higher values of emergence speed index, and in this period cultivar AS 7307 RR stood out regarding the others, showing higher ESI (15.55), followed by cultivars SYN 9070 RR, SYN 1283 RR and NK 7059 RR, which did not differ from each other, and cultivar SYN 1163 RR showed lower ESI. Seeds with higher ESI have better performance and consequently, higher emergence rate in the farming field, resisting better to stresses that may occur during emergence (Dan et al., 2010).

At 90 days of storage, cultivars AS 7307 RR and SYN 9070 RR showed higher vigor. With 180 days of storage it is noted that the higher index was seen for cultivar AS 7307 RR, followed by NK 7059 RR and SYN 1283 RR and the lowest vigor levels occurred for SYN 1163 RR and SYN 9070 RR (Table 3).

Observing each of the cultivars during storage (Table 3), it is seen that in general the seeds of the cultivars had higher vigor when not stored, lower throughput at 90 days of storage and an intermediate performance after 180 days of storage.

The highest emergence speed index at 180 days, when compared at 90 days, may be due to the fact that, even under controlled conditions, the temperature in the chamber of $25^{\circ} \mathrm{C}$ in August (the time when the assessment at 90 days was carried out) may have been influenced at night by the outside temperature when the photoperiod of 12 hours of dark occurred, because as the lamps were off, the temperature may have been reduced because there was no heating system, which probably did not influence the other storage times, which were held in early May and in November, high temperature periods in the city of Lavras. This result corroborates that obtained in the percentage of normal 
seedlings at 14 days in the emergence test in trays.

Given the results achieved in the implementation of the physiological tests, it was found that the damage caused by the artificial incidence of water in the pre-harvest was small due to the probable low water absorption by seeds. In the period before the harvests, rainfall indices were low, which shows the effect of the treatment applied. Although the amount of water applied by the irrigation system was relatively high $(30 \mathrm{~mm})$, it occurred in a concentrated form, which probably favored the low water uptake by the seeds and the rapid loss of moisture by pods, differently from what occurs when there is a natural rainfall with atmospheric conditions of high relative humidity, which provides higher absorption of water in the seeds and consequently higher moisture damage.

\section{Conclusions}

Among the cultivars studied, AS 7307 RR has a higher lignin content in the seeds tegument and a smaller percentage of moisture damage evaluated by the tetrazolium test in all harvest times.

Cultivars NK 7059 RR and SYN 1163 RR have the lowest lignin content in the integument and the highest percentages of moisture damage evaluated by the tetrazolium test in all harvest times.

Cultivar AS 7307 RR has the highest physiological performance and cultivar SYN 1163 RR the lowest, evaluated by germination and vigor tests.

Electrical conductivity values increase with seed storage for all cultivars.

The percentage of normal seedlings emergence and the emergence speed index vary with storage.

\section{Acknowledgments}

The authors thank FAPEMIG (Research Support Foundation of the Brazilian State of Minas Gerais), CNPq (National Counsel of Technological and Scientific Development)] and CAPES (Coordination of Improvement of Higher Education Personnel) for the financial support during the conduction of this study.

\section{References}

BRACCINI, A.L.; ALBRECHT, L.P.; ÁVILA, M.R.; SCAPIM, C.A.; BIO, F.E.I.; SCHUAB, S.R.P. Qualidade fisiológica e sanitária das sementes de quinze cultivares de soja (Glycine max (L.) Merrill) colhidas na época normal e após o retardamento de colheita. Acta Scientiarum Agronomy, v.25, n.2, p 449-457, 2003. http://dx.doi.org/10.4025/actasciagron.v25i2.2153
BRASIL. Ministério da Agricultura, Pecuária e Abastecimento. Regras para análise de sementes. Ministério da Agricultura, Pecuária e Abastecimento. Secretaria de Defesa Agropecuária. Brasília: MAPA/ACS, 2009. 395p. http:// www.agricultura.gov.br/arq_editor/file/2946_regras_analise_sementes.pdf

CAPELETI, I.; FERRARESE, M.L.L.; KRZYZANOWSKI, F.C.; FERRARESE FILHO, O. A new procedure for quantification of lignin in soybean (Glycine max (L.)Merrill) seed coat and their relationship with the resistance to mechanical damage. Seed Science and Technology, v.33, p.511-515, 2005. http://www.scielo.br/scielo.php?script=sci nlinks\&ref $=000084 \& \mathrm{pid}=\mathrm{S} 1413-7054201000020001500006 \& \operatorname{lng}=\mathrm{pt}$

CARVALHO, E.R.; OLIVEIRA, J.A.; CALDEIRA, C.M. Qualidade fisiológica de sementes de soja convencional e transgênica RR produzidas sob aplicação foliar de manganês. Bragantia, v.73, n.3, p.219-228, 2014 http://www.scielo.br/pdf/brag/2014nahead/aop_brag_0096_pt.pdf

DAN, L.G.M; DAN, H.A.; BARROSO, A.L.L; BRACCINI, A.L. Qualidade fisiológica de sementes de soja tratadas com inseticidas sob efeito do armazenamento. Revista Brasileira de Sementes, v.32, n.2, p.131-139, 2010 http://www.scielo.br/pdf/rbs/v32n2/v32n2a16.pdf

DINIZ, F.O.; REIS, M.S.; DIAS, L.A.S.; ARAÚJO, E.F.; SEDIYAMA, T., SEDIYAMA, C.A. Physiological quality of soybean seeds of cultivars submitted to harvesting delay and its association with seedling emergence in the field. Journal of Seed Science, v.35, n.2, p.147-152, 2013. http://www scielo.br/scielo.php?pid=S2317-15372013000200002\&script=sci_arttext

DUTRA, A.S.; VIEIRA, R.D. Envelhecimento acelerado como teste de vigor para sementes de milho e soja. Ciência Rural, v.34, n.3, p.715-721, 2004. http:/ www.scielo.br/scielo.php?pid=S0103-84782004000300010\&script=sci_arttext

FERREIRA, D.F. Sisvar: a computer statistical analysis system. Ciência e Agrotecnologia, v.35, n.6, p.1039-1042, 2011. http://www.scielo.br/scielo. php?pid=S1413-70542011000600001\&script=sci_arttext

FORTI, V.A.; CARVALHO, C.; TANAKA, F.A.O; CICERO, S.M. Weathering damage in soybean seeds: assessment, seed anatomy and seed physiological potential. Seed Technology, v.35, n.2, p.213-224, 2013. http://www researchgate.net/profile/Cristiane_De_Carvalho/publication/268385544 Weathering_Damage_in_Soybean_Seeds_Assessment_Seed_Anatomy and_Seed_Physiological_Potential/links/5469 $\mathrm{cdbe} 0 \mathrm{cf} 2 \mathrm{f} 5 \overline{\mathrm{eb}} 1805 \overline{1} \mathrm{c} 35 . \mathrm{pdf}$

FRANÇA-NETO, J.B.; KRZYZANOWSKI, F.C.; COSTA, N.P. O teste de tetrazólio em sementes de soja. Londrina: Embrapa Soja, 1998. 72p. (EmbrapaCNPSo. Documentos, 116). http://www.scielo.br/scielo.php?script=sci nlinks\&ref $=000079 \&$ pid $=$ S0101-3122201200010002000009\&lng $=$ en

GIURIZATTO, M.I.K.; SOUZA, L.C.F.; ROBAINA, A.D.; GONÇALVES M.C. Efeito da época de colheita e da espessura do tegumento sobre a viabilidade e o vigor de sementes de soja. Ciência e Agrotecnologia, v.27, n.4, p.771-779, 2003. http://www.scielo.br/scielo.php?script=sci arttext\&pid $=$ S1413-70542003000400005

GRIS, C.F.; VON PINHO, E.V.R.; ANDRADE, T.; BADONI, A.; CARVALHO, M.L.M. Qualidade fisiológica e teor de lignina no tegumento de sementes de soja convencional e transgênica RR submetidas a diferentes épocas de colheita. Ciência e Agrotecnologia, v.34, n.2, p.374-381, 2010. http://www.scielo.br/pdf/cagro/v34n2/15.pdf

HENNING, F.A.; JACOB JUNIOR, E.A.; MERTZ, L.M.; PESKE, S.T. Qualidade sanitária de sementes de milho em diferentes estádios de maturação. Revista Brasileira de Sementes, v.33, n.2, p.316-321, 2011. http://www.scielo. br/scielo.php?pid=S0101-31222011000200014\&script=sci_arttext 
LIMA, W.A.A.; BORÉM, A.; DIAS, D.C.F.S.; MOREIRA, M.A.; DIAS, L.A.S.; PIOVESAN, N.D. Retardamento de colheita como método de diferenciação de genótipos de soja para qualidade de sementes. Revista Brasileira de Sementes, v.29, n.1, p.186-192, 2007. http://www.scielo.br/ scielo.php?script=sci_arttext\&pid=S0101-31222007000100026

MAGUIRE, J.D. Speed of germination-aid in selection and evaluation for seedling emergence and vigor. Crop Science, v.2, n.1, p.176-177, 1962. http:// www.scielo.br/scielo.php?script=sci_nlinks\&ref $=000106 \&$ pid $=$ S0100$6762200300050000100017 \& \operatorname{lng}=\mathrm{pt}$

MENEZES, M.; VON PINHO, E.V.R.; JOSÉ, S.C.B.R.; BALDONI, A.; MENDES, F.F. Aspectos químicos e estruturais da qualidade fisiológica de sementes de soja. Pesquisa Agropecuária Brasileira, v.44, n.12, p.1716-1723, 2009. http://www.scielo.br/scielo.php?pid=S0100204X2009001200022\&script $=$ sci_arttext

MINUZZI, A.; BRACCINI, A.L.; RANGEL, M.A.S.; SCAPIM, C.A.; BARBOSA, M.C.; ALBRECHT, L.P. Qualidade de sementes de quatro cultivares de soja, colhidas em dois locais no estado do Mato Grosso do Sul. Revista Brasileira de Sementes, v.32, n.1, p.176-185, 2010. http://www. scielo.br/scielo.php?pid=S0101-31222010000100020\&script=sci_arttext

OLIVEIRA, G.P.; ARAÚJO, D.V.; ALBUQUERQUE, M.C.F.; MAGNANI, E.B.Z.; MAINARDI, J.T. Avaliação física, fisiológica e sanitária de sementes de soja de duas regiões de Mato Grosso. Revista Agrarian, v.5, n.16, p.106114, 2012. http://www.periodicos.ufgd.edu.br/index.php/agrarian/article/ viewArticle/1039

PANOBIANCO, M.; VIEIRA, R.D.; KRZYZANOWSKI, F.C.; FRANÇA-NETO, J.B. Electrical conductivity of soybean seed and correlation with seed coat lignin content. Seed Science and Technology, v.27, n.3, p.945-949, 1999. http://www.scielo.br/scielo.php?script=sci_ nlinks\&ref=000103\&pid=S0006-8705201000010002600019\&lng $=$ pt
PELÚZIO, J.M.; FIDELIS, R.R.; JÚNIOR, D.A.; SANTOS, G.R.; DIDONET, J. Comportamento de cultivares de soja sob condições de várzea irrigada no sul do estado do Tocantins, entressafra 2005. Bioscience Journal, v.24, n.1, p.75-80, 2008. http://www.seer.ufu.br/index.php/biosciencejournal/ article/view/6734

SANTOS, E.L.; PÓLA, J.N.; BARROS, A.S.R.; PRETE, C.E.C. Qualidade fisiológica e composição química das sementes de soja com variação na cor do tegumento. Revista Brasileira de Sementes, v.29, n.1, p.20-26, 2007. http://www. scielo.br/scielo.php?pid=S0101-31222007000100003\&script=sci_arttext

SCHUAB, S.R.P.; BRACCINI, A.L.; FRANÇA-NETO, J.B.; SCAPIM, C.A.; MESCHEDE, D.K. Potencial fisiológico de sementes de soja e sua relação com a emergência das plântulas em campo. Acta Scientiarum Agronomy, v.28, n.4, p.553-561, 2006. http://www.scielo.br/scielo.php?script=sci nlinks\&ref $=000113 \& \mathrm{pid}=\mathrm{S} 1807-8621201100020001600020 \& \operatorname{lng}=\mathrm{en}$

VIEIRA, R.D.; KRZYZANOWSKI, F.C. Teste de condutividade elétrica In: KRZYZANOWSKI, F.C.; VIEIRA, R.D.; FRANCA-NETO, J.B. (Ed.) Vigor de sementes: conceitos e testes. Londrina: ABRATES, 1999. p. 1-26.

VILLIERS, T.A. Ageing and longevity of seeds in field conditions. In: HEYDECKER, W. (Ed.). Seed Ecology, London: The Pennsylvania State University, 1973. p.265-288. 